\section{Милена Жикић}

Фармацеутски факултет, Нови Сад

Катедра за општеобразовне предмете milenazikic85@gmail.com

DOI: $10.18485 /$ rit.2022.20.37.9
UDK: 321.64:929 Хитлер A.

94(100)“1939/1945“

Прегледни рад

Датум пријема: 20.09.2020.

\title{
КОРЕНИ ВЛАДАВИНЕ УЖАСА АДОЛФА ХИТЛЕРА
}

\begin{abstract}
Резиме
Циљ раgа је gа иррикаже корене Хийлерове влаgавине иерора. У раgу ћемо се

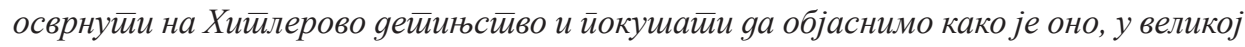
мери, уиициало на њеїово касније йолитиичко деловање.
\end{abstract}

Кључне речи: Хийлер, Алојс, Клара, дейињстиво, Јевреји, Беч.

\section{Увод}

Век који је за нама оставио је неизбрисиве догађаје и владаре. Био је један од најбурнијих векова у историји човечанства, испуњен мноштвом ратова, који је почео и завршио се великим бројем жртава. Са сигурношћу се може рећи да су Први и Други светски рад однели велики број људских живота и били прекретница за нека даља дешавања. Оно што можемо уочити данас, на почетку 21. века, јесте да је Адолф Хитлер, у великој мери обележио 20. век. Остао је упамћен у историји као човек несаломивих идеја и визија, који је желео да изгради нови свет и створи нови поредак.

Несвакидашњи вођа, Адолф Хитлер, оставио је дубок траг у историји Немачке. Период његове владавине окарактерисан је као један од најтежих периода у историји човечанства. Бројна злодела наметнула су му епитет ,gикйайор Немачке“. По његовој директиви побијено је шест милиона европских Јевреја, Рома, хомосексуалаца, као и ментално и физички заосталих лица, који су сматрани нижом расом. Оно што поткрепљује и оправдава надимак иичранин, јесте чињеница да је свет увео у рат у којем је живот изгубило милионе мушкараца, жена и деце, при чему је више од половине било цивила. Оправдано се може рећи да је, дванаест година Хитлерове владавине трајно изменило Немачку, Европу, свет као и ток историји.

У својству вође нацистичке Немачке, Хитлер се сматра једном од најодговорнијих особа за Други светски рад и Холокауст, у којем су почињени 
неки од највећих злочина против човечанства у историји. Основао је и покренуо страховиту машину уништавања милиона недужних људи - Јевреja, Руса, Пољака, Срба, Словенаца. Једноставно, људи који нису припадали аријевцима завршавали су живот у гасним коморама и крематоријима. Владавина Адолфа Хитлера донела је много несреће и јада. Велики број породица остао је без потомка са неком урођеном маном, јер није био подобан за усавршавање потомства.

Владавина Адолфа Хитлера могла би се с оправдањем окарактерисати као владавина без милости и осећања. Крајње одлучно, сурово и енергично спровео је физичко уништење милиона недужних људи, од деце, младежи, особа средњег доба, до немоћника и стараца. Уништио је човечанство, убијајући велике ствараоце у области медицине, хемије, менталне хигијене, а убијањем великог броја Јевреја убио је и велики део света.

Његова визија била је стварање једне немачке нације која ће се налазити изнад свих и бити господар свих народа, који ће морати да јој се покоре. Хитлерова диктатура је трајала дванаест година. За собом је оставила раскомадану Немачку, опустошену бомбардовањима, осиромашену за 4 милиона мртвих. Међутим, уколико се жртвама рата додају и они који су умрли у логорима, може се рећи да је 20 милиона људи страдало вољом једног јединог човека. По Хитлеру требало је уништити Јевреје, јер су сматрани непријатељима Немачке и успоставити доминацију над читавим европским простором - што је представљало полазну основу за овладавање целим светом. Према Хитлеровим виђењима Јевреји у Немачкој нису могли бити одрживи, те их је требало уклањати са суровошћу и без преседана. На корене Хитлерове владавине терора, било посредно било непосредно, указивали су и радови аутора:

Keršo Jan, ${ }^{1}$

Brenan Dž. Herbert, ${ }^{2}$

Infield B.Glenn, ${ }^{3}$

Klod David, ${ }^{4}$

Smiljanić Radomir, ${ }^{5}$ 2004.

1 Hitler 1889-1936: Hibris, Beograd 2003; Hitler 1936-1945: Nemezis, Beograd

2 Okultni rajh, Beograd 2000.

3 Eva i Adolf, Zagreb 1976.

4 Hitler i nacizam, Beograd 1999.

5 Mein Kampf Adolfa Hitlera: Prevod, polemički komentari i razmatranja knjige, Zrenjanin 2001. 


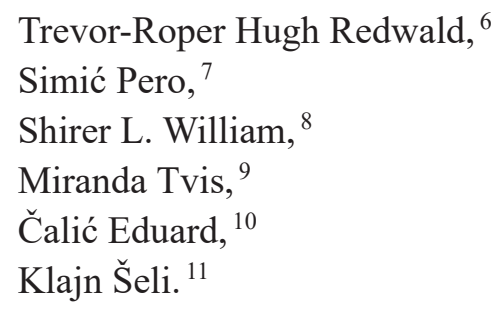

\section{Детињство}

Адолф Хитлер, је рођен 20. априла 1889. године у аустријском граничном граду Браунау на Ину, аустријско-баварској граници, као четврто од шесторо деце цариника Алојса Хитлера и његове жене Кларе (рођене Пелцл). Од све деце само су преживели он и његова сестра Паула, која је била ментално заостала. ${ }^{12}$

Хитлеров отац, Алојс Хидлер (1837-1903), био је ванбрачни син Марије Ане Шиклгрубер ${ }^{13}$ - Хитлерова баба. Године 1842. Марија се удала за Јохана Георга Хидлера. Брак је трајао пет година, јер је Марија 1847. умрла, а Хидлер деценију касније. Бригу о детету преузео је Јохан Непомук, млађи брат Јохана Георга. Дечак је добио скроман дом и усвојитеље, који су му омогућили успешан завршетак основног школовања и изучавање кожарског заната. Својим трудом, радом и залагањем уздигао је породицу на друштвеној лествици. Године 1870. постао је царински службеник, а 1875. инспектор царине у Браунау на Ину.

Године 1876. дошло је до великог преокрета у животу Алојса. Те године Алојс је променио презиме тј. прихватио је презиме Хидлер/Хитлер. ${ }^{14}$ У преводу презиме Хитлер значи ситни сопственик. Питање које се намеће је: Одакле је потекла иницијатива за променом презимена? Прва могућ-

6 Poslednji Hitlerovi dani, Beograd 2006.

7 Neizvesna prošlost: fašizam, nacionalsocijalizam, staljinizam, Beograd 1986.

8 Uspon i pad trećeg raicha: uspon Adolfa Hitlera, trijumf i konsolidacija, Zagreb 1977.

9 Najveći zlotvori u istoriji: muškarci i žene, Beograd 2004.

10 Hitler bez maske:tajni razgovori Hitler-Breiting iz 1931. godine, Pula 1985.

11 Najveći zlotvori u istoriji: diktatori, Beograd 2004.

12 Infield, Eva i Adolf, 26.

13 Шиклгрубери су генерацијама били ситносопственичка породица у Валдфиртелу, сиромашној и шумовитој регији на крајњем северозападу Доње Аустрије, на граници са Бохемијом.

14 Називи Hiedler, Hietler, Huttler, Hutler, Hitler налазе се у различитим облицима у документима и веома их је тешко фонетски разликовати. 
ност је од Непомука, Алојсовог поочима, који је лишен мушких наследника, ${ }^{15}$ условио Алојса да ће добити наслеђе уколико прихвати његово презиме. Од тог тренутка у Матичној књизи рођених презиме Шиклгрубер замењено је у Хитлер, док је у рубрици намењеној имену оца уписано име Јохан Хитлер. ${ }^{16}$

Друго питање, које такође привлачи пажњу је: Зашто за време свог живота Георг Хидлер није признао свог сина, уколико је он стварно био његов отац? Сумње које су се јавиле, након уписивања очинства отвориле су ново поље интересовања за утврђивање очинства Алојсовог. Наиме, све више се сумњало да је прави отац Алојса Шиклгрубера, заправо његов поочим тј. стриц, рођени брат Георга Хидлера. Оно што продубљује ову проблематику је и чињеница да је Непомук Хидлер инсистирао на промени презимена три године после смрти своје супруге Еве Марије, у жељи да његов син буде и његов наследник. ${ }^{17}$

Веома важан моменат у животу Алојса био је његов брак са Кларом Пелцл, коме су предходила још два. Прва његова супруга, са којом је склопио брак 1875. године, била је Ана Гласл, старија од њега 14. година. У овом браку материјални моменат је био од великог значаја. Наиме, Ана је била жена са јаком финансиском потпором и поред тога имала је и чврсте везе у јавним службама, што је одговарало Алојсу. Међутим, брак са старијом женом није успео да се одржи, те је убрзо (1880.) уследио и развод, условљен Алојсовим неверством. Наиме, касних седамдесетих година XIX века, Алојс је био у интимној вези са младом служавком Франциском Фани Макелбергер са којом је склопио брак 1883. године, након развода и смрти прве супруге Ане. Оно што се може уочити, на први поглед, јесте велика разлика у годинама између Фани и Алојса. Наиме, друга његова животна сапутница била је млађа од њега 22 године. Међутим, и овај брак није успео да се одржи, јер се млада Фани разболела од туберкулозе у 23-ој години живота и умрла. И поред свега, брак је био крунисан децом: сином Алојсом-млађим и ћерком Ангелом. ${ }^{18}$

15 Непомук је имао искључиво женско потомство и био ожењен педесетогодишњакињом, дефинитивно је био преокупиран настављањем породичног имена. Најбоља могућност, која се указала односила се на Алојса тј. да он као усвојеник настави породично име.

16 Опширније о проблему промене презимена види: Keršo, Hitler-Hibris, 35-37.

17 Сажет приказ породичног проблема око промене презимена види: Keršo, HitlerHibris, 37.

18 Shirer, Uspon i pad, 46. 
Наредне, 1884. године Алојс се оженио, блиском рођаком Кларом Пелцл, ${ }^{19}$ која је још од 1876. године, са навршених шеснаест година, почела да ради као служавка у домаћинству Алојса Хитлера. Била је уклоњена из куће од стране друге Алојсове супруге Фани, која је у њој видела могућу супарницу, јер је само годину дана била старија од ње. Међутим, болест Фанина је условила повратак Кларе Пелцли. Овај пут преузела је бригу о деци и била у улози дадиље. Услед њиховог зближавања Клара је остала у другом стању што је убрзало склапање брака, након добијања црвене сагласности због родбинских веза. Венчање је обављено 7. јануара 1885. године. Тако је Алојс, по трећи пут себи одабрао за сапутницу девојку која је 23. године била млађа од њега. ${ }^{20}$ Треба имати у виду да су родбинске везе оставиле велике последице. Наиме, последње рођено дете било је ментално заостало, док су остала деца, сем Адолфа и његове сестре Пауле, преминула. ${ }^{21}$

Трећи брак донео је пуно деце. Наиме, Клара је пре Адолфа родила Густава, Иду и Ота, али је Адолфово рођење било праћено великом трагедијом у породици тј. смрћу сестре Иде и брата Ота. Тако да је Хитлер био прво дете које је преживело рано детињство. Пар година касније (1894.) Адолф је добио брата Едмунда, који је 1900. године преминуо. Пола деценије касније родила се Паула која је заједно са Хитлером преживела тешке године родитељског брака. ${ }^{22}$

Породични живот породице Хитлер био је без имало хармоније и среће. Алојс се све време трудио да буде свима надређен у кући. Сходно томе, он је тежио да буде ауторитативан и заповеднички настројен супруг и отац. Као човек био је доста крут, без смисла за шалу, безосећајан, штедљив, непредвидив, педантно тачан, посвећен својим дужностима. Сфера његовог интересовања нису била деца и њихово одгајање, већ пчеларство и пиво, према чему је показивао велику страст. Његов живот сводио се на пиће и жене. ${ }^{23}$ У таквом окружењу Клара је делила живот са крајње ауторитативним

19 Клара Пелцл - Klara Polzl - унука Непомука Хидлера, ћерка Јохане Хитлер и Јохана Пелцла, мајка Адолфа Хитлера. Клара је постала блиска рођака Алојсу после промене презимена и утврђивање очинства. Дакле, Клара је била ћерка Непомукове најстарије ћерке Јохане, док је Алојс био син Непомуковог брата Георга Хидлера. Дакле, након промене презимена и утврђивања очинства Јохана, мајка Кларина, и Алојс су постали брат и сестра, тако да је Клара постала Алојсу сестричина а он њој ујак. Да су родбинске везе биле јаке и дефинитивно нераскидиве говори и чињеница да је Клара често свога супруга, рођака, у браку

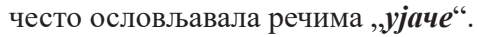

20 Сажет приказ Алојсових бракова види: Keršo, Hitler-Hibris, 41-42.

21 Infield, Eva i Adolf, 26.

22 Keršo, Hitler-Hibris, 43.

23 Infield, Eva i Adolf, Zagreb 1976, 26. 
супругом. У најтежим тренуцима, када је остала без деце, Адолф јој је пружао сву љубав, али се као дечак није много радовао. Паулине изјаве указују да се Адолф супротстављао често оцу због чега је добијао батине. Брижну мајку Клару Адолф је јако волео. ${ }^{24}$

Клара Пелцл, унука Непомука Хитлера и ћерка Јохана Пелцла и Јохане Хитлер, према сведочењима јеврејског лекара Едуарда, била је једноставна, скромна, нежна, послушна, повучена, тиха, побожна, заокупљена кућним пословима, сасвим супротна личност у односу на супруга Алојса. ${ }^{25}$ Често је била изложена тренуцима агресије супруга. Батине и тортуре подносила је беспоговорно, трудећи се да заштити од њих децу. Адолф се тако, још у свом најранијем детињству, упознао са тешким призорима агресивног понашања оца. Немоћан да помогне мајци, а жестоко присутан на њеној страни, постао је очајан и крајње рањив. ${ }^{26}$ У оцу је видео безосећајну звер. ${ }^{27} \mathrm{C}$ друге стране, Алојс Хитлер био је крајње суров према Адолфу и често га кажњавао, док је Адолф непрестано живео у страху од њега.

У сећањима Хитлеровог полубрата Алојса и полусестре Анђеле, очувало се сећање на суров очев однос према Адолфу и на тешке батине које је морао да поднесе. Адолфова мајка, иначе њихова маћеха, покушавала је да заштити сина: „Вияевщи gа ошиаи не може gа савлаgа свој необуздани їнев, уйлашена, оялучила је gа заустиави йо злостивљьње. Пойурила је своја ле-

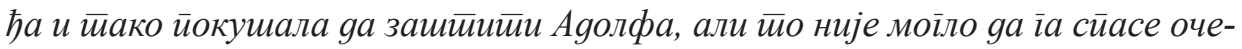
вux ygapau̧a.“ 28

Чињеница, која потврђује да је Адолф волео више мајку од оца јесте његов исказ у књизи „Моја борба“: „Пошитовао сам своїа оияа, али сам волео своју мајку.“ Као даља потврда ове константације јесте фотографија Кларе Пелцл, коју је непрестано са собом носио током живота, чак и у бункеру, док су се портрети са њеним ликом налазили у његовим становима у Минхену и Берлину. Сматра се, да је мајка била једина особа коју је током живота волео. ${ }^{29}$

Адолфово рано детињство, најрањивији период, проведено је у породици којом је доминирао строг отац, блага и брижна мајка. Адолфова сестра Паула често је говорила, да је атмосфера у породици била динамична и че-

$24 \mathrm{http} / / \mathrm{hr}$.wikipedia.org/wiki/Adolf_Hitler

25 Keršo, Hitler-Hibris, 43-44.

26 Klajn, Najveći zlotvori, 71-72.

27 Tvis,Najveći zlotvori u istoriji, 224.

28 Keršo, Hitler-Hibris, 44.

29 Keršo, Hitler-Hibris, 44. 
сто се сводила на свађу око деце. Такође се у сећању Хитлера очувао сваки очев шамар који је уследио у тренуцима када би Алојс плануо. Горки призори детињства који су се очували у сећању Хитлера, током целог живота, у великој мери су утицали на формирање страха према оцу, као и одсуство љубави. За разлику од мајке коју је волео свим срцем, оца је мрзео. У тренуцима када је Алојс тукао Адолфа, Клара је стајала са друге стране врата и слушала мужевљеве изливе беса. Такође, Алојсов бес упућен Клари није био скривен од очију деце која су, у великој мери, присуствовала тешким сценама у којима је пијан отац тукао мајку. Са сигурношћу се може рећи, да су поменути очеви поступци утицали на развој Адолфовог карактера и да су догађаји из детињства оставили велике последице на његов каснији живот и утицали на формирање Адолфа кога је свет запамтио под именом Хитлер. ${ }^{30}$ Корене владавине ужаса у Трећем рајху и логорима смрти треба тражити у детињству Адолфа Хитлера.

Детињство Адолфа Хитлера такође је било обележено и честим променама пребивалишта. Наиме, због посла Алојса Хитлера, породица се често селила. Очево одсуство, мали Едмунд, заокупљеност мајке бебом, посвећеност полубрата и полусестре школи узроковали су да Адолф преузме бригу о домаћинству. Обавезе и окружење били су најпресуднији у погледу појаве беса уколико се догађаји нису одвијали како је желео. ${ }^{31}$ Нови моменти беса настали су након Алојсовог пензионисања и његовог боравка у кући са децом. То је утицало да његов први син Алојс Млађи напусти кућу, те су Едмунд и Адолф остали једини дечаци у породици. Догађај који је у потпуности променио живот у кући, била је још једна трагедија тј. смрт млађег брата Едмунда. Тако је сплет околности условио да Адолф постане једино мушко дете у породици, а животно окружење утицало на формирање склоности ка вођству које је показивао у играма полицајаца и пљачкаша. ${ }^{32}$

\section{Ране године}

Први школски дани Адолфа Хитлера, који су отпочели 1. маја 1895. године, били су обележени успехом о чему су сведочиле високе оцене. Међутим, у свом раду није показао истрајност и доследност. Поставља се питање колико су прилике у породици утицале на његово даље напредовање у шко-

30 Isto, 44-45.

31 Keršo, Hitler-Hibris, 46.

32 Isto, 46. 
ли? Сматра се, да се драстично погоршавање односа са оцем одразило на његов успех у школи. Регресија у школовању бележи се уписивањем средње школе. Наиме, године 1900. Адолф је уписао средњу школу и понављао први разред. Разлози за незаинтересованост у школи били су личне природе. Проблем који се јавио тицао се Адолфове будућности. Алојс је желео да од Хитлера створи успешног службеника док је Хитлер желео да постане сликар. Петогодишње школовање од 1900-1905. године обележено је лошим успехом у школи и поправним испитима. Сви покушаји Алојса да причама из свог живота постакне љубав или вољу за позив чиновника код свог сина нису уродили плодом. Тако је отац остао доследан у намери да Адолф никада не постане уметник, док Адолф није одустао од намере да буде уметник. ${ }^{33}$ Незаинтересованост у школи био је добар разлог да покаже неспособност за учењем, заправо да поступи по очевим жељама и постане службеник. То је изазивало велики бес код Алојса, који се манифестовао још већим ауторитетом. Овакав однос условио је да Адолф (1903.) израсте у беспосленог, озлојеђеног, тврдоглавог и бунтовног младића. Такође, у школи је од својих другова захтевао послушност и иступао као предводник. На савете или замерке реаговао је скривеним непријатељством. ${ }^{34}$ Овај период трајао је све до Алојсове смрти, 1903. година, када престаје највећи родитељски притисак. ${ }^{35}$ Након чега се посвећује сликању и сањарењу. Изграђивао је имагинарни свет у коме је видео себе. ${ }^{36}$ Епилог је уследио (1905) када је напустио школу, у 16-ој години живота. ${ }^{37}$

У периоду од 1905. до 1907. Адолф се спремао за упис Бечке Ликовне академије. Две године живео је живот беспосличара, окружен пажњом мајке. Слободно време користио је за сликање, цртање, читање или писање поезије. Вечери су пролазиле у посетама позоришту и опери. Били су то најсрећнији дани његовог живота. Био је фасциниран Вагнером, који је у његовим очима израстао у супериорног уметничког генија.

33 Shirer, Uspon i pad, 50; Smiljanić, Mein Kampf, 9.

34 Tvis, Najveći zlotvori u istoriji, 224.

35 Infield, Eva i Adolf, 26.

36 Опширније о Хитлеровим страстима према Вагнеру, музици, уметности и архитектури види: Keršo, Hitler-Hibris, 54-55, 79-80.

37 Сажет приказ Хитлерових средњошколских дана даје: Keršo, Hitler-Hibris, 48-53. 


\section{„Бечке године“ (1908-1913)}

Нова етапа у животу Адолфа Хитлера отпочела је 1906. године још једним доласком у Беч. Свој боравак у Бечу описао је на следећи начин: „За мене је Беч, град који је толикима био појам недужне забаве, свечано поприште раздраганих људи, на жалост само живи спомен најтужнијег раздобља у мом животу. ${ }^{38 ، ~}[\ldots]$ И данас још може овај град да у мени побуди само суморне мисли. Пет година беде и јада су у мени садржани у имену овога града. Пет година за које сам најпре као помоћни радник, потом као малешни сликар, морао себи да зарађујем хлеб; мој ваистину мршави, оскудни хлеб, који никада и није био довољан да би се утолила и најобичнија глад.“ 39

Први долазак у Беч догодио се 1906. године. Том приликом посетио је ликовну галерију при Дворском музеју и две седмице уживао је у знаменитостима Беча. Наредни долазак уследио је 1907. године у циљу полагања пријемног испита на Академији лепих уметности. Убрзо по доласку поднео је молбу за пријем у Бечку академију уметности и Бечку академију архитектуре, али ни на једном месту није био примљен. Ово је била још једна кап која је пунила душу незадовољством, појачала постојећи гнев из детињства и допринела да он остане у њему до краја живота. Његово велико разочарење исказано је речима: “Био сам у тој мери сигуран да ћу успети, да ме је негативан одговор погодио као гром из ведра неба.” 40

Целокупан његов живот у Бечу може се окарактерисати као борба за голу егзистенцију. ${ }^{41} \mathrm{y}$ току бечких година Адолфова мајка озбиљно је оболела од рака и подвргнута оперативном захвату. ${ }^{42}$ Породична трагедија усле-

38 Shirer, Uspon i pad, 59.

39 Smiljanić, Mein Kampf, 17.

40 Keršo, Hitler-Hibris, 57.

41 Детаљније о тешким бечким данима видети: Smiljanić, Mein Kampf, 20-23.

42 Беч је обликовао младог Хитлера. У том граду Хитлер је почео да мрзи Јевреје. Наиме, Хабзбуршка монархија била је многонационална држава коју су чинили Немци, Чеси, Словаци, Пољаци, Словенци, Срби, Хрвати, Италијани, Румуни и Мађари. Међу њима налазила се велика јеврејска национална мањина. Јевреји су и у Бечу оставили значајан историјски белег на основу њиховог учешћа у целокупној градској популацији у различитим занимањима, научном животу, медијима, уметности, привреди и финансијама. У Бригитенауу, депресивном делу града у коме је Хитлер провео последње три године свога боравка у Бечу, чак $17 \%$ становништва чинили су Јевреји. То је било окружење у коме је Хитлер у потпуности био окружен расном мржњом. У тако многољудној држави Немци су се осећали запостављеним и по њима је требало забранити Јеврејима досељавање у Беч. Јевреји су били крупни финансијери. Највеће незадовољство према Јеврејима показивали су припадници нижих и средњих класа тј. они чија је егзистенција била угрожена. Један од најдоминантнијих представника уништења Јевреја био је градоначелник Беча Лигер кога је касније следио Хитлер. 
дила је 21. децембра 1907. године када је Клара Хитлер умрла у 47-ој години живота од рака дојке: "Изіубио сам јеgину особу ирема којој сам осећао бли-

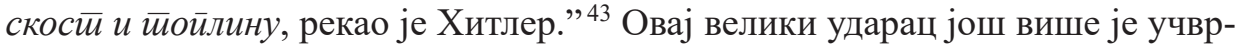
стио Адолфа у његовим намерама да постане архитекта. Међу психолозима влада уверење да је Хитлер несвесно мрзео Јевреје између осталог и зато што лекар његове мајке, који је био Јеврејин, није успео да јој излечи рак. Касније, када је изгубио своју мајку и када му је друга мајка постала Немачка, он је желео да излечи Немачку од рака, односно од Јевреја. Временом је Немачка све више заузимала положај његове мајке, а код њега се јављао изопачени нагон за осветом и поравнањем. ${ }^{44}$

Сиромаштво и сурова стварност натерали су Адолфа да превазиђе све препреке. Такође, оно што га је учврстило у намерама, да не одустаје, јесте његов отац који је захваљујући свом труду, прешао пут од сиромаха до државног службеника. Фебруара 1908. године Хитлер се вратио у Беч, град који је оставио неизбрисив траг на њега и утицао на формирање његових предрасуда и страхова. Трећи долазак у Беч $(1908-1913)$, био је најдужи и најпресуднији у његовом животу. Поново се опробао у полагању пријемног испита из сликарства и доживео неуспех. Од тада, па све до краја живота, живео је живот испуњен горчином и мржњом према свима који су одбили да га прихвате, као и према вршњацима који су били боље среће од њега. У таквим, све друго само не природним амбијентима, израстао је у насилну и безобзирну личност, чија је једина опсесија била да постане у животу "неко", не бирајући средства како да циљ и оствари. Када је дошао на власт, политиком теpopa, покушао је да надохнади све неостварене жеље из младости. ${ }^{45}$

У књизи Моја борба описао је долазак и боравак у Бечу: „Где год да сам ишао примећивао сам Јевреје. И што сам их више посматрао, то су се они у мојим очима све јасније издвајали од остатака људског рода.“ Од тог тренутка мржња према Јеврејима је све више и више расла. Они су били узрок сваког зла. Они су били оличење бестидности, прљавштине, проституције, трговине белим робљем. У очима Адолфа Хитлера они су били велико дно до краја његовог живота. Њима је приписао одговорност за Други светски рат. ${ }^{46}$ Према његовом виђењу, девет десетина литерарне прљавштине, уметничког кича и позоришне бесмислице припада Јеврејима. ${ }^{47}$ Разочаран, сме-

43 Keršo, Hitler-Hibris, 58.

$44 \mathrm{http} / / / \mathrm{www}$. astrologyinserbia.com/s/thebest/petkovic13.htm

45 Детаљно о Хитлеровом боравку у Бечу види: Keršo, Hitler-Hibris, 63-110.

46 Shirer, Uspon i pad, 70.

47 Smiljanić, Mein Kampf, 43. 
стио се у бедно коначиште близу реке где је животарио цртајући плакате за мале привреднике. Дакле, живео је живот од данас до сутра и притом се све више временом повлачио у себе. У принципу, опробао се на неколико радних места као сликар акварела, цртач разгледница и слично.

Гледајући с једне стране, Хитлеров боравак у Бечу био је од великог значаја јер је дао подстицај његовом политичком деловању. Наиме, видевши како се Аустро-Угарска монархија распала под притиском њених националности, у њему се развила свест о надмоћности Немаца. ${ }^{48}$ У двадесет и четвртој години, пролеће 1913, Адолф је напустио Беч да би избегао регрутацију у аустријској војсци. Главне побуде за одлазак из Аустрије и избегавање војне обавезе биле су подстакнуте жељом да се избегне служење војске са Јеврејима, Словенима и осталим националним мањинама у царству. ${ }^{49}$ Ипак, учествовао је у рату и стекао чин каплара.

Након Аустрије отишао је у Минхен где је наставио изолован живот. За време Адолфовог боравка у Минхену Јевреји су уточиште пронашли у поменутом граду, бежећи масовно од прогона у Русији и источној Европи, а нарочито из Пољске и Мађарске. У Минхену је схватио да су Јевреји инфериорна раса и одговорни за сва зла овог света. У књизи Мајн камйф написао je: „Јевреји су били одговорни за довођење црнаца у Рајнску област, с идејом прљања беле расе коју мрзе и деградирања њеног културног и политичког нивоа да би Јевреји могли да владају.“ 50

После рата, почео је да окупља исфрустриране ратне ветеране, расисте и антисемите. Августа 1920. постао је председник Немачке радничке партије, којој је променио име у Немачка национал-социјалистичка радничка партија и истој осмислио нови програм, који се темељио на расизму и национализму. Успео је да привуче незадовољне масе, али је временом задобио и симпатије високих кругова немачког крупног капитала и војске који су спремали освету за пораз из Великог рата. Његова жеља, да у Немачкој изведе пуч била је осујећена. Хитлер је осуђен на пет година робије, али је издржао само једну. У затвору је напиосао књигу Моја борба која је постала програм нацизма.

У условима велике беде и сиромаштва које је владало у Немачкој, Хитлер је стицао све већу популарност као човек чврсте руке који може да заведе ред. Страх од комунизма и јаког радничког покрета у Немачкој, као и

48 David, Hitler, 11.

49 Shirer, Uspon i pad, 70.

50 Klajn, Najveći zlotvori, 73-74. 
британска подршка, знатно су ојачали нацисте и питање њиховог доласка на власт била је опора реалност. Током 1934. године Хитлер је преузео сву власт постао канцелар, председник Републике и врховни командант оружаних снага. Прогласио се за Фирера, вођу немачког народа, обновитеља Царства. После тога, уследили су сурови обрачуни са политичким противницима у његовим редовима, затим са опозицијом и геноцид против Јевреја. Системом јавних радова у функцији јачања војне моћи, готово да је искорењена незапосленост, подигнут је стандард обичног становништва и створена је илузија о друштву среће и благостања, о друштву националног-социјализма. Многи Немци поверовали су у то и, опијени илузијом о моћи и величини своје нације и државе, слепо су следили вођу.

\section{Закључак}

Вођа нациста и немачки канцелар Адолф Хитлер, најмрачнија је личност новије историје. Геноцид и диктатура, јесте историја Хитлерове визије велике Немачке која је свет довела на ивицу пропасти. Цели народи били су на ивици истребљења, милиони људи страдали су у концентрационим логорима, највише Руси, Пољаци, Јевреји. Тешко је рећи кога је Хитлер више мрзео: Јевреје или Словене, или можда Русе. Хитлерова епоха биће сигурно упамћен по грађењу највећег и најопаснијег концентрационог логора на свету - Аушвица, у коме је побијено више милиона Јевреја, Пољака и других народа. Хитлер је сматрао да је он апсолутни господар Трећег Рајха, као и свих Немаца и других покорених народа. Да подсетимо, кроз Други светски рат Хитлер је наредио систематски прогон и убијање милиона европских Јевреја, Словена, а осим тога Рома, хомосексуалаца и инвалида. Кључну улогу у овим злочинима имала је немачка тајна полиција Гестапо која је од 1936. год. била задужена за оснивање и управљање концентрационим логорима, прво у Немачкој, а затим и на окупираним територијама. На крају рата схватио је да није успео да окупира и заузме целу Европу што је био његов сан, који се није претворио у јаву. Остварење његовог сна донео би свету још већи број жртава, а тиме би и размере геноцида биле још веће.

Основно питање које се поставља гласи: Где треба тражити корене владавине ужаса? На основу изнетих података са оправдањем се може закључити, да је тешко и напорно детињство, непостојање породичне хармоније дало печат Хитлеровој личности и њеном формирању кроз живот. Први тешки шамари и батине од оца, утицали су да Хитлер одрасте у једну тврдо- 
главу, упорну и изнад свега јако огорчену особу која је током живота желела да Немачку спаси од Јевреја, највећих непријатеља.

Јевреји су у Хитлеровој глави до последњег дана живота остали гамад и све зло овог човечанства. Они су били на свим водећим позицијама у Немачкој, они су довели Немачку до слома у Првом светском рату, имали моћ и утицај, док је он беспомоћно, гладно и бедно живео у Бечу. И као што смо већ нагласили, неки психолози сматрају да је Хитлер несвесно мрзео Јевреје између осталог и зато што лекар његове мајке, који је био Јеврејин, није успео да јој излечи рак. Касније, када је изгубио своју мајку, а када му је друга мајка постала Немачка, он је желео да излечи Немачку од рака, односно од Јевреја. Немачка је временом све више заузимала положај његове мајке, а код њега се јављао изопачени нагон за осветом. То је била раса коју је требало уништити и заувек истребити са овог света. Визионар и велики идеалиста није успео да оствари свој највећи сан покоравање Русије. Но ипак, је успео да спроведе своју политику геноцида тзв. Холокауст. Корени ужаса усађени у детињству дефинитивно су добили још веће сокове даљим бивствовањем.

У закључним разматрањима можемо издвојити да је дванаест година Хитлерове владавине трајно изменило Немачку, Европу и свет. Хитлер је био владар који је променио ток историји. Век којим је доминирало његово име, карактерише рат и геноцид. Био је и остао необјашњив историјски феномен. Човек са скромним интелектуалним и друштвеним вредностима, без искуства у вршењу власти, обележио је човечанство и оставио читав свет без даха.

Хитлера идеје су заживеле, али нису преживеле. Владавина ужаса остаће упамћена генерацијама и питање које се поставља је: Да ли ће икада политика гвожђа и крви Адолфа Хитлера бити заборављена, а свет оправљен од великих геноцида у 20. веку? Можда би то могла бити нова тема за будућа истраживања.

\section{Литература}

Brenan Dž. Herbert, Okultni rajh, Beograd 2000.

Čalić Eduard, Hitler bez maske:tajni razgovori Hitler-Breiting iz 1931. godine, Pula 1985. Infield B.Glenn, Eva i Adolf, Zagreb 1976.

Klajn Šeli, Najveći zlotvori u istoriji: diktatori, Beograd 2004.

Klod David, Hitler i nacizam, Beograd 1999.

Лакер Волтер, Историја Европе: 1945-1992, Београд 1999.

Lee Stephen J., Hitler and Nazi Germany, London : Routledge, 2010. 
Shirer L. William, Uspon i pad trećeg raicha: uspon Adolfa Hitlera, trijumf i konsolidacija, Zagreb 1977.

Simić Pero, Neizvesna prošlost: fašizam, nacionalsocijalizam, staljinizam, Beograd 1986. Smiljanić Radomir, Mein Kampf Adolfa Hitlera: Prevod, polemički komentari i razmatranja knjige, Zrenjanin 2001.

Trevor-Roper Hugh Redwald, Poslednji Hitlerovi dani, Beograd 2006.

Jan Keršo, Hitler 1889-1936: Hibris, Beograd 2003.

Jan Keršo, Hitler 1936-1945: Nemezis, Beograd 2004.

Miranda Tvis, Najveći zlotvori u istoriji: muškarci i žene, Beograd 2004.

Електронски извори:

http://www.astrologyinserbia.com/s/thebest/petkovic13.htm

Milena Žikić

Faculty of Pharmacy, Novi Sad

Department of General Education Sciences

milenazikic85@gmail.com

\section{THE ROOTS OF THE REIGN OF THE HORROR OF ADOLF HITLER}

\section{Summary}

The aim of the paper is to show the roots of Hitler's rule of terror. In this paper, we will look at Hitler's childhood and try to publish how it, to a large extent, influenced his delays in political activity.

Keywords: Hitler, Alois, Clara, childhood, Jews, Vienna. 